\title{
DEAGREGASI BENCANA GEMPA BANJARMASIN DAN PERBANDINGAN KURVA HAZARD DENGAN SUMBER GEMPA SESAR
}

\author{
Tirsa Fajrin Mochtar') , Nurul Puteri Matdoan ${ }^{2)}$, \\ Della Natasya Putri ${ }^{3)}$, Imam Trianggoro Saputro $\left.{ }^{4}\right)$ \\ 1),2),3),4) Program Studi Teknik Sipil, Universitas Muhammadiyah Sorong \\ Email :ctirsactirsa@gmail.com
}

\begin{abstract}
ABSTRAK
Kota Banjarmasin adalah ibu kota provinsi Kalimantan Selatan, Indonesia. Banjarmasin yang dijuluki Kota Seribu Sungai ini memiliki wilayah seluas $98,46 \mathrm{~km}^{2}$ yang wilayahnya merupakan delta atau kepulauan yang terdiri dari sekitar 25 buah pulau kecil (delta) yang dipisahkan oleh sungai-sungai di antaranya pulau Tatas, pulau Kelayan, pulau Rantauan Keliling, pulau Insan dan lain-lain.[4] Berdasarkan data BPS Kota Banjarmasin tahun 2016, Banjarmasin memiliki penduduk sebanyak 675.440 jiwa dengan kepadatan 9.381 jiwa per $\mathrm{km}^{2}$.[5] Wilayah metropolitan Banjarmasin yaitu Banjar Bakulamemiliki penduduk sekitar 1,9 juta jiwa. Kota Banjarmasin terletak pada $3^{\circ} 15^{\prime}$ sampai $3^{\circ} 22^{\prime}$ Lintang Selatan dan 114³2' Bujur Timur, ketinggian tanah asli berada pada $0,16 \mathrm{~m}$ di bawah permukaan laut dan hampir seluruh wilayah digenangi air pada saat pasang. Kota Banjarmasin berlokasi daerah kuala sungai Martapura yang bermuara pada sisi timur Sungai Barito. Letak Kota Banjarmasin nyaris di tengah-tengah Indonesia , kota Banjarmasin Dari seluruh catatan Indeks Resiko Bencana yang disusun BNPB, Ibu Kota Provinsi Banjarmasin memiliki risiko bencana gempa bumi. Sebanyak 55,88 persen (19 kota/kab.) memiliki risiko tinggi gempa bumi, dan 44,12 persen risikonya tingkat sedang. Kota Banjarmasin beriklim sabana tropis di mana angin muson barat bertiup dari Benua Asia melewati Samudera Hindia menimbulkan musim hujan, sedangkan angin dari Benua Australia adalah angin kering yang berakibat adanya musim kemarau. Curah hujan yang turun rata-rata per tahunnya kurang lebih 2.400 mm dengan fluktuasi tahunan berkisar antara 1.600$3.500 \mathrm{~mm}$, jumlah hari hujan dalam setahun kurang lebih 150 hari dengan suhu udara yang sedikit bervariasi, sekitar $26^{\circ} \mathrm{C}$. Kota Banjarmasin termasuk wilayah yang beriklim tropis. Angin Muson dari arah Barat yang bertiup akibat tekanan tinggi di daratan Benua Asia melewati Samudera Hindia menyebabkan terjadinya musim hujan.
\end{abstract}

Kata Kunci : Deagregasi bencana gempa, Banjarmasin

\section{PENDAHULUAN}

Kota Banjarmasin adalah ibu kota provinsi Kalimantan Selatan, Indonesia. Banjarmasin yang dijuluki Kota Seribu Sungai ini memiliki wilayah seluas $98,46 \mathrm{~km}^{2}$ yang wilayahnya merupakan delta atau kepulauan yang terdiri dari sekitar 25 buah pulau kecil (delta) yang dipisahkan oleh sungai-sungai di antaranya pulau Tatas, pulau Kelayan, pulau Rantauan Keliling, pulau Insan 
dan lain-lain.[4] Berdasarkan data BPS Kota Banjarmasin tahun 2016, Banjarmasin memiliki penduduk sebanyak 675.440 jiwa dengan kepadatan 9.381 jiwa per $\mathrm{km}^{2}$.[5] Wilayah metropolitan Banjarmasin yaitu Banjar Bakulamemiliki penduduk sekitar 1,9 juta jiwa. Kota Banjarmasin terletak pada $3^{\circ} 15^{\prime}$ sampai $3^{\circ} 22^{\prime}$ Lintang Selatan dan $114^{\circ} 32^{\prime}$ Bujur Timur, ketinggian tanah asli berada pada $0,16 \mathrm{~m}$ di bawah permukaan laut dan hampir seluruh wilayah digenangi air pada saat pasang. Kota Banjarmasin berlokasi daerah kuala sungai Martapura yang bermuara pada sisi timur Sungai Barito. Letak Kota Banjarmasin nyaris di tengah-tengah Indonesia, kota Banjarmasin Dari seluruh catatan Indeks Resiko Bencana yang disusun BNPB, Ibu Kota Provinsi Banjarmasin memiliki risiko bencana gempa bumi. Sebanyak 55,88 persen (19 kota/kab.) memiliki risiko tinggi gempa bumi, dan 44,12 persen risikonya tingkat sedang. Kota Banjarmasin beriklim sabana tropis di mana angin muson barat bertiup dari Benua Asia melewati Samudera Hindia menimbulkan musim hujan, sedangkan angin dari Benua Australia adalah angin kering yang berakibat adanya musim kemarau. Curah hujan yang turun rata-rata per tahunnya kurang lebih $2.400 \mathrm{~mm}$ dengan fluktuasi tahunan berkisar antara 1.600$3.500 \mathrm{~mm}$, jumlah hari hujan dalam setahun kurang lebih 150 hari dengan suhu udara yang sedikit bervariasi, sekitar $26^{\circ} \mathrm{C}$. Kota Banjarmasin termasuk wilayah yang beriklim tropis. Angin Muson dari arah Barat yang bertiup akibat tekanan tinggi di daratan Benua Asia melewati Samudera Hindia menyebabkan terjadinya musim hujan. sedangkan tekanan tinggi di Benua Australia yang bertiup dari arah Timur adalah angin kering pada musim kemarau. Hujan lokal turun pada musim penghujan, yaitu pada bulan-bulan November-April. Dalam musim kemarau sering terjadi masa kering yang panjang. Curah hujan tahunan rata-rata sampai $2.628 \mathrm{~mm}$ dari hujan per tahun 156 hari. Suhu udara rata-rata sekitar $25^{\circ} \mathrm{C}-38^{\circ} \mathrm{C}$ dengan sedikit variasi musiman. Fluktuasi suhu harian berkisar antara $74-91 \%$, sedangkan pada musim kemarau kelembabannya rendah, yaitu sekitar 52\% yang terjadi pada bulan-bulan Agustus,

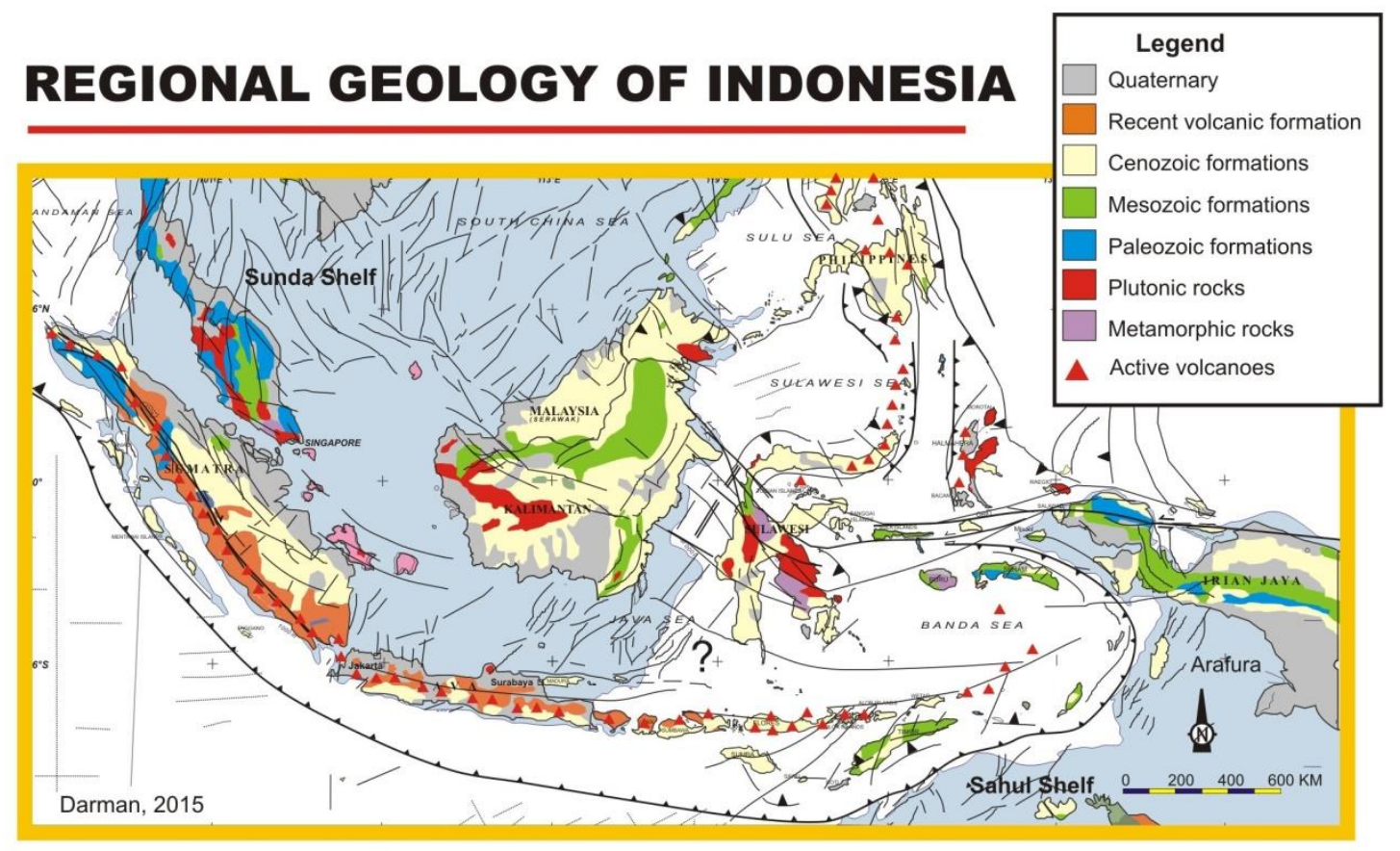

Gambar . sketsa tektonik Banjarmasin 

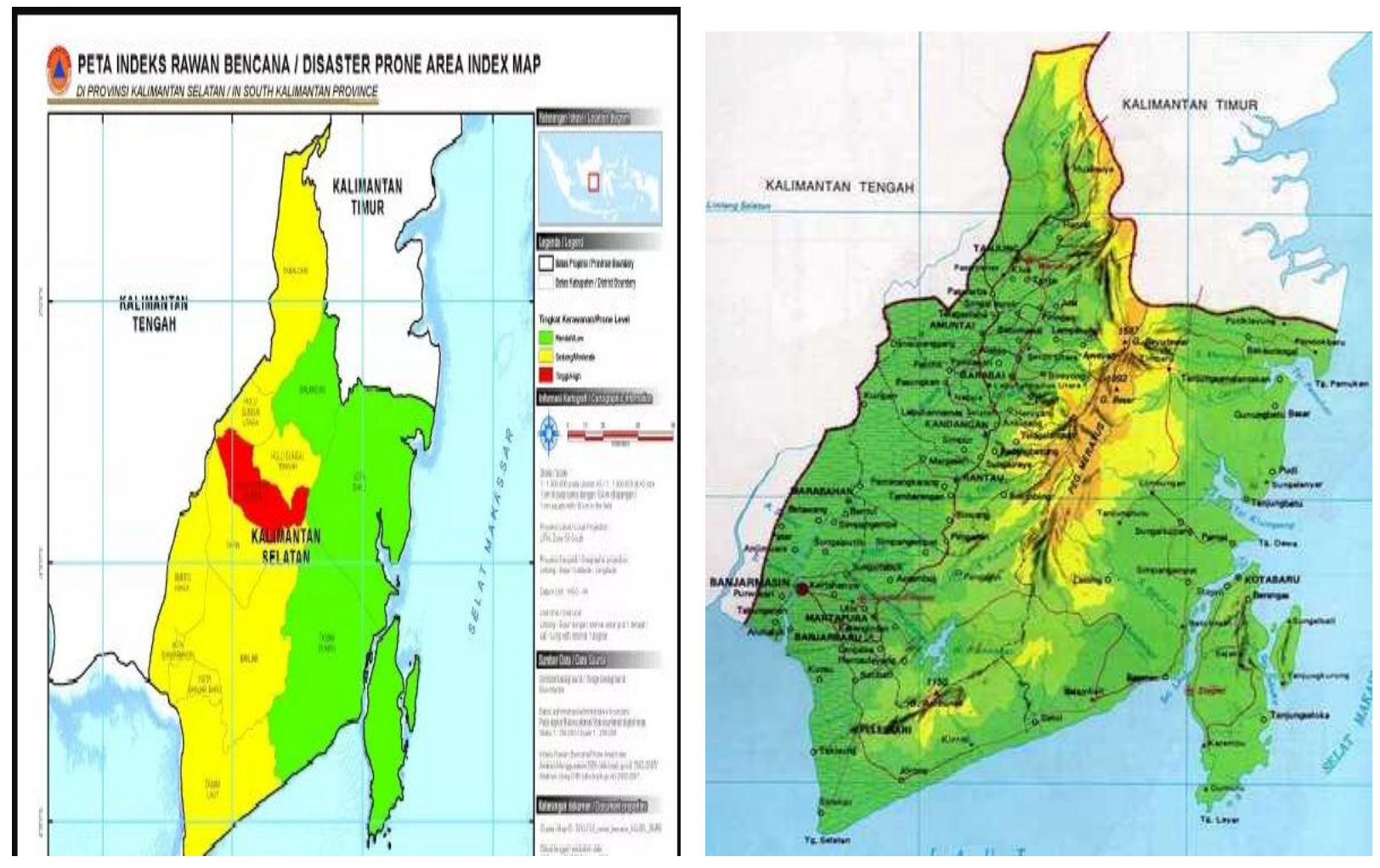

Gambar . (a) Sketsa elevasi peta digital banjarmasin dan (b) detail peta Banjarmasin dan sekitarnya, ,data percepatan tanah masih sangat sedikit, sehingga pada umumnya dalam analisis menggunakan data percepatan tanah (ground acceleration) dari wilayah lain, bahkan dalam Standar Nasional Indonesia (SNI) 03-1726-2002 di rekomendasikan menggunakan empat buah akselerogram dari empat gempa yang berbeda, salah satunya harus diambil dari data gempa Elcentro 1940 komponen N-S (Irsyam dkk.,2008). Pemakaian data percepatan tanah (ground acceleration) dari wilayah atau negara lain belum tentu sesuai diterapkan untuk semua wilayah di Indonesia. Data percepatan tanah memegang peranan yang penting untuk mendapatkan hasil analisis dinamik yang akurat. Oleh karena itulah, pemilihan data percepatan tanah ini harus sesuai dengan kondisi geologi, seismologi, dan target parameter pergerakan batuan dasar seperti percepatan gempa maksimum, kandungan frekuensi dan durasi (Irsyam dkk.,2008). Mengingat parameter percepatan tanah dan respons spektra memegang peranan penting dalam penyusunan peraturan kegempaan,maka penelitian percepatan tanah dan respons spektra yang sesuai untuk Kota Banjarmasin menjadi sangat penting untuk dilakukan. Penelitian tentang rekomendasi percepatan tanah untuk Kota Banjarmsin pernah dilakukan oleh Teguh dan Purwono (2011), namun masih sebatas desain percepatan tanah pada batuan dasar dengan periode ulang gempa 500 tahun. Peraturan gempa modern saat ini sudah mengacu pada penggunaan periode ulang 
gempa 2.500 tahun, sehingga rekomendasi percepatan tanah untuk Kota Banjarmasin dengan periode ulang gempa 500 tahun perlu ditinjau kembali. Dalam penelitian sebelumnya Sunardi (2013) telah menentukan percepatan tanah yang sesuai untuk Kota Banjarmasin yang mengacu pada periode ulang gempa 2.500 tahun. Penelitian ini melengkapi penelitian sebelumnya dengan menekankan penggunaan teknik spectral matching menggunakan algoritma wavelet (Abrahamson,1992; Hancockdkk.,2006).

\section{PEMBAHASAN}

Ada beberapa metode yang dapat digunakan dalam Seismic Hazard Assessment untuk membuat prediksi kejadian gempa di masa yang akan datang (gempa rencana). Metode-metode itu diantaranya adalah The Gumbel Type I method, The Line Source Method, The Total Probability Area Method dan The EQ Occurrence Distributed.

Pada tugas kali ini, Seismic Hazard Assessment menggunakan The Line Source Method untuk membuat Hazardcurve yang dapat memperkirakan kejadian gempa di Kota Banjarmasin. Rumus Atenuasi yang digunakan adalah atenuasi Donofan (1973), Campbell (1990), Campbell (1993), dan Alfaro (1990). Kota Banjarmasin terletak pada $3^{\circ} 15^{\prime}$ sampai $3^{\circ} 22^{\prime}$ Lintang Selatan dan $114^{\circ} 32^{\prime}$ Bujur Timur,

\section{Metode}

Refensi dalam penelitian ini mengikuti Azmi, Rafiqul (2017) dan Firmansyah(1999), Untuk urutan metode yang digunakan dalam penelitian ini adalah sebagai berikut:
a. Mengidentifikasi koordinat kota Banjarmasin.
b. Menganalisis jarak maks. $100 \mathrm{~km}$ dari titik episenter gempa bumi.
c. Membuat kurva hazard hasil dari analisis.
d. Kesimpulan

\section{Menghitung Fungsi Atenuasi}

Pada analisis resiko gempa apabila lokasi yang ditinjau (site interest) tidak mempunyai data rekaman gempa, maka untuk memperkirakan besarnya percepatan maksimum tanah digunakan fungsi atenuasi. Yang dimaksud dengan fungsi atenuasi adalah suatu fungsi yang menggambarkan korelasi antara intensitas (i) gerakan tanah setempat, magnitude (M) dan jarak (R) dari sumber titik dalam daerah sumber gempa. Memperkirakan fungsi atenuasi untuk gerakan tanah akibat gempa telah menjadi subjek yang menarik dalam penelitian bidang kegempaan. Fungsi atenuasi merupakan alat yang penting dalam mengaplikasikan resiko 
kegempaan dalam perencanaan bangunan tahan gempa. Faktor-faktor yang mempengaruhi fungsi atenuasi adalah :

1. Mekanisme Gempa

2. Jarak Episenter

3. Kondisi Tanah Lokal

Fungsi Atenuasi CAMPBELL (1993)

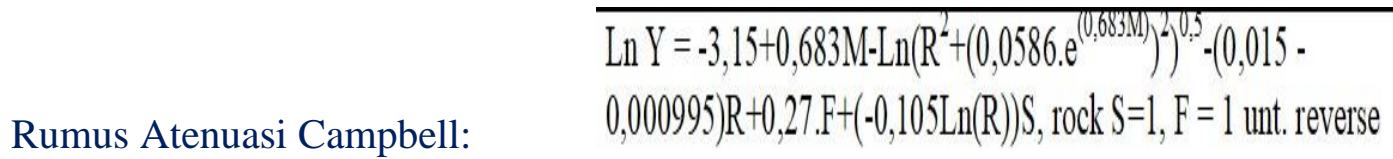

Perhitungan :

Menggunakan : $\quad M=6$

$\mathrm{R} \quad=15 \mathrm{Km}$

$\mathrm{F} \quad=1$

$\mathrm{S} \quad=1$

$\operatorname{Ln} \mathrm{Y}=-3.15+0.683 \mathrm{M}-\mathrm{Ln}\left(\mathrm{R}^{\wedge} 2+\left(0.0586 * \mathrm{e}^{\wedge}(0.683 \mathrm{M})\right)^{\wedge} 2\right)^{\wedge} 0^{*} 5-(0.015-0.000995) \mathrm{R}+0.27 * \mathrm{~F}+(-$

$0.105 \operatorname{Ln}(\mathrm{R})) \mathrm{S}$ 
Tabel 1.1. Contoh Hasil Perhitungan Atenuasi Campbell

\begin{tabular}{|c|c|c|}
\hline $\mathrm{NO}$ & $\mathrm{R}$ & $\mathrm{Y}$ \\
\hline 1 & -0.0956 & 0.908823 \\
\hline 2 & -0.28304 & 0.753487 \\
\hline 3 & -0.4723 & 0.623566 \\
\hline 4 & -0.65771 & 0.518038 \\
\hline 5 & -0.83256 & 0.434935 \\
\hline 6 & -0.99446 & 0.369923 \\
\hline 7 & -1.14349 & 0.318704 \\
\hline 8 & -1.28072 & 0.277837 \\
\hline 9 & -1.40748 & 0.244759 \\
\hline 10 & -1.52509 & 0.217602 \\
\hline 11 & -1.63471 & 0.195009 \\
\hline 12 & -1.73735 & 0.175986 \\
\hline 13 & -1.83388 & 0.159792 \\
\hline 14 & -1.92503 & 0.145872 \\
\hline 15 & -2.01141 & 0.133801 \\
\hline 16 & -2.09354 & 0.12325 \\
\hline 17 & -2.17188 & 0.113963 \\
\hline 18 & -2.24681 & 0.105736 \\
\hline 19 & -2.31866 & 0.098406 \\
\hline 20 & -2.38771 & 0.091839 \\
\hline 21 & -2.45423 & 0.08593 \\
\hline 22 & -2.51841 & 0.080587 \\
\hline 23 & -2.58047 & 0.075738 \\
\hline 24 & -2.64056 & 0.071321 \\
\hline 25 & -2.69885 & 0.067283 \\
\hline & & \\
\hline 100 & -5.27184 & 0.005134 \\
\hline & & \\
\hline
\end{tabular}

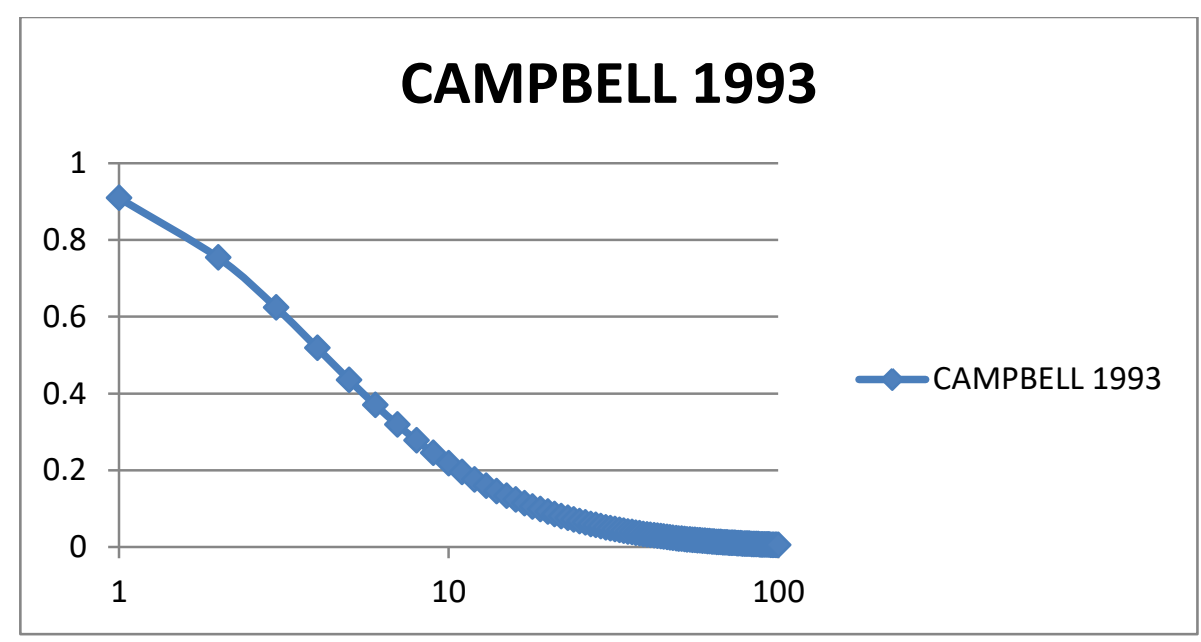


Fungsi Atenuasi CAMPBELL (1990)

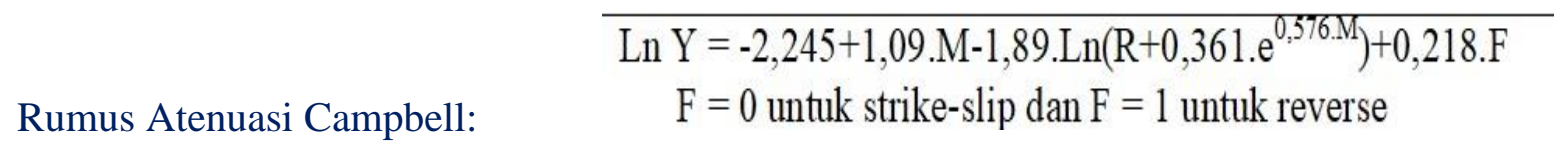

Perhitungan :

Menggunakan : $\quad \mathrm{E} \quad=2.718282$

$$
\begin{aligned}
& \mathrm{M}=6 \\
& \mathrm{R}=15 \mathrm{Km}
\end{aligned}
$$

Ln $\mathrm{Y}=-2.245+1.09 * \mathrm{M}-1.89 * \operatorname{Ln}\left(\mathrm{R}+0.361 * \mathrm{e}^{\wedge} 0.576 * \mathrm{M}\right)+0.218 * \mathrm{~F}$

Tabel 1.2. Contoh Hasil Perhitungan Atenuasi Campbell (1990)

\begin{tabular}{|c|c|c|}
\hline $\mathrm{NO}$ & $\mathrm{R}$ & $\mathrm{Y}$ \\
\hline 1 & 1.527516 & 0.423643 \\
\hline 2 & 1.173419 & 0.159922 \\
\hline 3 & 0.875311 & -0.13318 \\
\hline 4 & 0.617879 & -0.48146 \\
\hline 5 & 0.391346 & -0.93816 \\
\hline 6 & 0.189081 & -1.66558 \\
\hline 7 & 0.006385 & -5.05376 \\
\hline 8 & -0.1602 & -1.83135 \\
\hline 9 & -0.31328 & -1.16066 \\
\hline 10 & -0.45488 & -0.78771 \\
\hline 11 & -0.58662 & -0.53338 \\
\hline 12 & -0.70976 & -0.34283 \\
\hline 13 & -0.82537 & -0.19192 \\
\hline 14 & -0.93432 & -0.06794 \\
\hline 15 & -1.03732 & 0.036642 \\
\hline 16 & -1.135 & 0.126635 \\
\hline 17 & -1.22788 & 0.20529 \\
\hline 18 & -1.31641 & 0.274908 \\
\hline 19 & -1.40098 & 0.337169 \\
\hline 20 & -1.48192 & 0.393338 \\
\hline 21 & -1.55954 & 0.44439 \\
\hline 22 & -1.63409 & 0.491089 \\
\hline 23 & -1.70582 & 0.534047 \\
\hline 24 & -1.77493 & 0.573759 \\
\hline 25 & -1.84159 & 0.61063 \\
\hline & & \\
\hline 100 & -4.26223 & 1.449792 \\
\hline & & \\
\hline
\end{tabular}




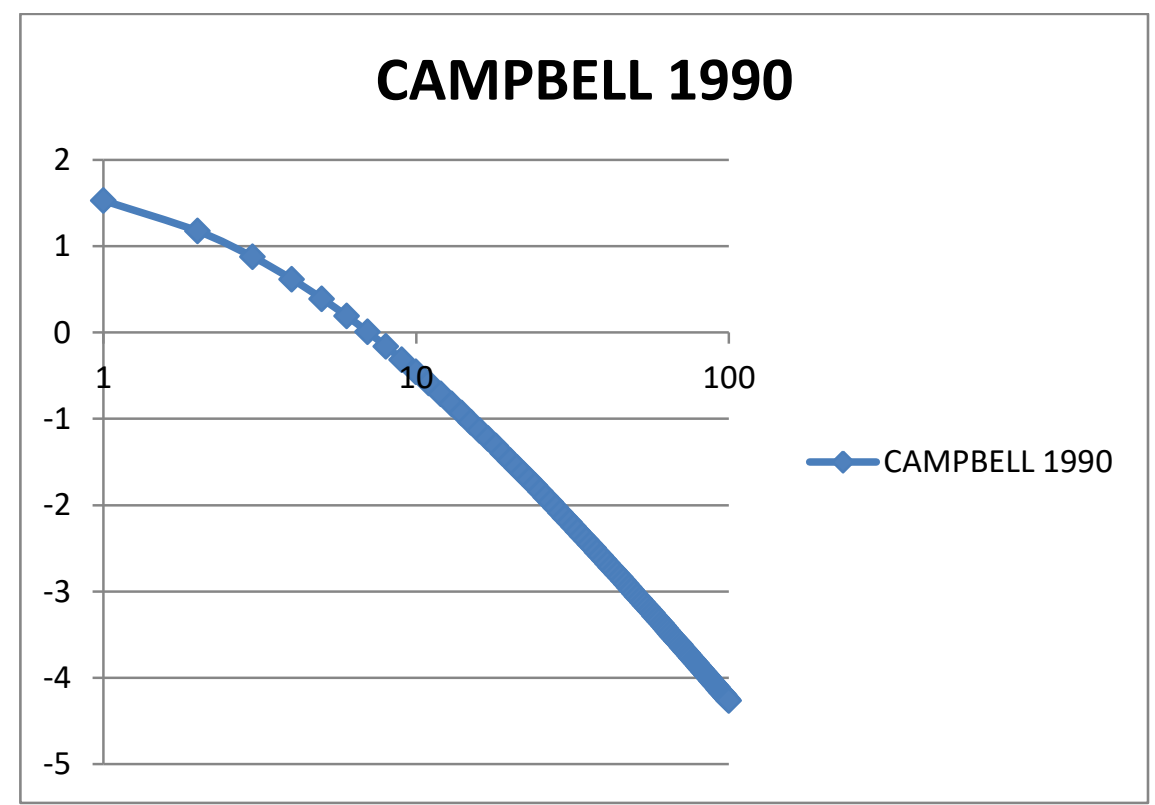

Fungsi Atenuasi DANOVAN (1973)

Rumus Atenuasi Donavan: $\quad \mathrm{Y}=1080 . \mathrm{e}^{0.5 . \mathrm{M}}(\mathrm{R}+25)^{-1.32}$

Perhitungan :

Menggunakan : $\quad \mathrm{E} \quad=2.718282$

$$
\begin{array}{ll}
\mathrm{M} & =6 \\
\mathrm{R} & =15 \mathrm{Km}
\end{array}
$$

$\log Y=1080 * e^{\wedge}(0.5 * M) *(R+25)^{\wedge}-2$ 
Tabel 1.3. Contoh Hasil Perhitungan Atenuasi Donavan (1973)

\begin{tabular}{|c|c|c|}
\hline NO & $\mathrm{R}$ & $\mathrm{Y}$ \\
\hline 1 & 32.08932 & 3.468523 \\
\hline 2 & 29.75635 & 3.393043 \\
\hline 3 & 27.66885 & 3.320307 \\
\hline 4 & 25.79356 & 3.250125 \\
\hline 5 & 24.10264 & 3.182322 \\
\hline 6 & 22.57272 & 3.116742 \\
\hline 7 & 21.18396 & 3.053245 \\
\hline 8 & 19.91954 & 2.991701 \\
\hline 9 & 18.76503 & 2.931995 \\
\hline 10 & 17.70807 & 2.87402 \\
\hline 11 & 16.73795 & 2.817678 \\
\hline 12 & 15.84542 & 2.76288 \\
\hline 13 & 15.02242 & 2.709544 \\
\hline 14 & 14.26192 & 2.657593 \\
\hline 15 & 13.55774 & 2.606957 \\
\hline 16 & 12.90445 & 2.557572 \\
\hline 17 & 12.29727 & 2.509377 \\
\hline 18 & 11.73195 & 2.462316 \\
\hline 19 & 11.20474 & 2.416337 \\
\hline 20 & 10.71229 & 2.371391 \\
\hline 21 & 10.2516 & 2.327434 \\
\hline 22 & 9.82 & 2.284421 \\
\hline 23 & 9.415095 & 2.242314 \\
\hline 24 & 9.034727 & 2.201076 \\
\hline 25 & 8.676952 & 2.16067 \\
\hline & & \\
\hline 100 & 1.388312 & 0.328089 \\
\hline & & \\
\hline
\end{tabular}

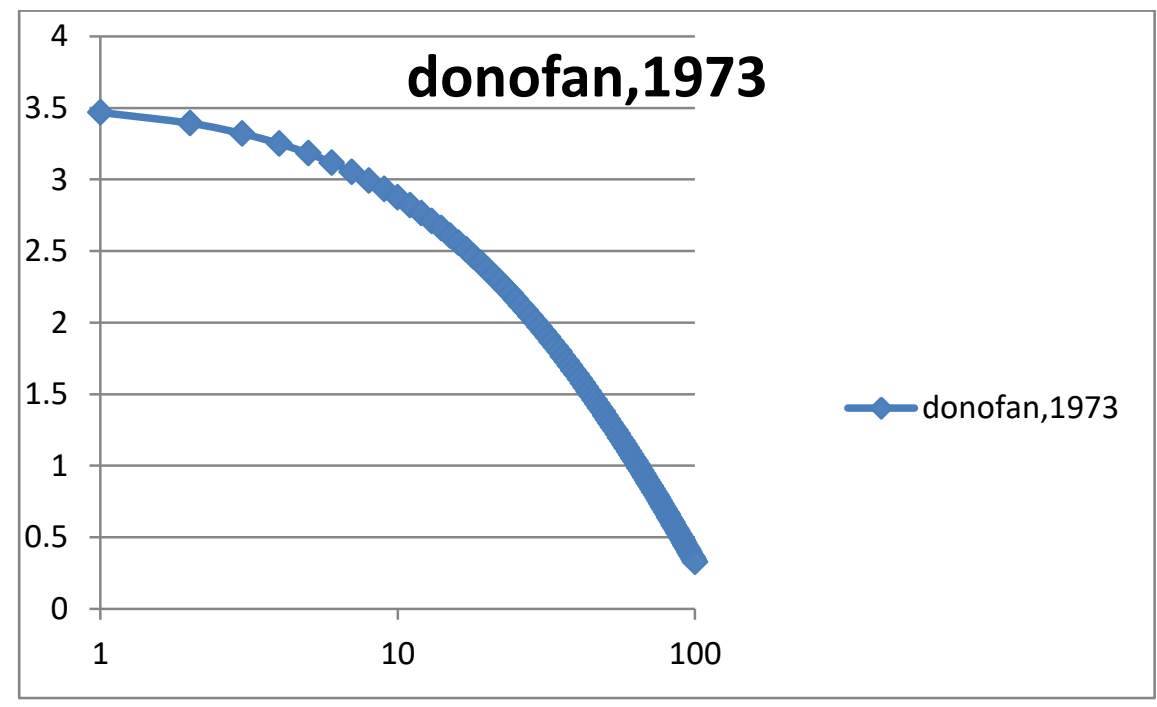




\section{Fungsi Atenuasi ALFARO (1990)}

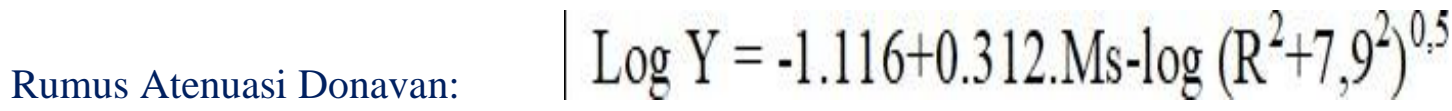

Perhitungan :

Menggunakan : $\quad \mathrm{E} \quad=2.718282$

$$
\begin{array}{ll}
M & =6 \\
R & =15 \mathrm{Km}
\end{array}
$$

$\log Y=-1.116+0.312^{*} M s-\log \left(R^{\wedge} 2+7.9^{\wedge} 2\right)^{\wedge} 0.5$

\begin{tabular}{|c|c|c|}
\hline NO & $\mathrm{R}$ & $\mathrm{Y}$ \\
\hline 1 & -0.58644 & -0.23177 \\
\hline 2 & -0.5939 & -0.22629 \\
\hline 3 & -0.60553 & -0.21787 \\
\hline 4 & -0.62036 & -0.20736 \\
\hline 5 & -0.6374 & -0.19559 \\
\hline 6 & -0.65575 & -0.18326 \\
\hline 7 & -0.67471 & -0.17088 \\
\hline 8 & -0.69375 & -0.1588 \\
\hline 9 & -0.71253 & -0.1472 \\
\hline 10 & -0.73081 & -0.13619 \\
\hline 11 & -0.74847 & -0.12583 \\
\hline 12 & -0.76542 & -0.1161 \\
\hline 13 & -0.78165 & -0.10699 \\
\hline 14 & -0.79716 & -0.09845 \\
\hline 15 & -0.81196 & -0.09046 \\
\hline 16 & -0.82608 & -0.08298 \\
\hline 17 & -0.83956 & -0.07595 \\
\hline 18 & -0.85243 & -0.06934 \\
\hline 19 & -0.86473 & -0.06312 \\
\hline 20 & -0.87649 & -0.05725 \\
\hline 21 & -0.88775 & -0.05171 \\
\hline 22 & -0.89854 & -0.04646 \\
\hline 23 & -0.9089 & -0.04148 \\
\hline 24 & -0.91884 & -0.03676 \\
\hline 25 & -0.9284 & -0.03226 \\
\hline & & \\
\hline 100 & -0.58387 & -0.23368 \\
\hline & & \\
\hline
\end{tabular}




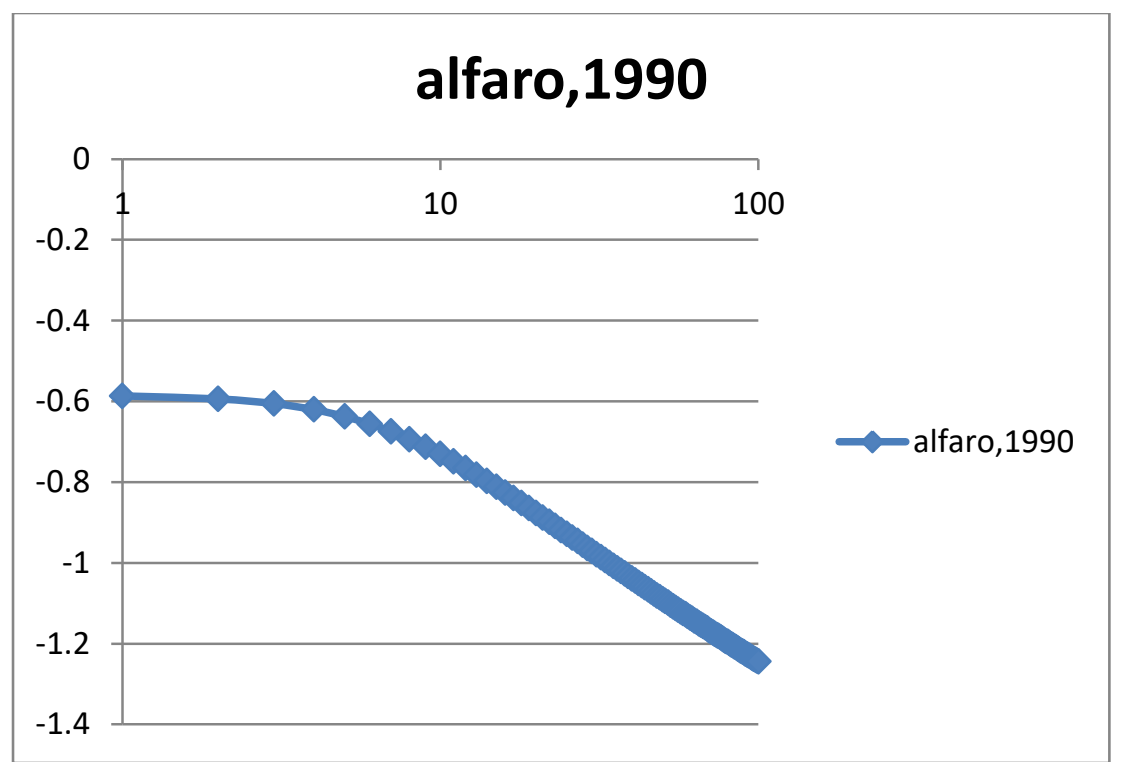

\section{Perbandingan Fungsi-Fungsi Atenuasi}

Setelah melakukan analisis dengan menggunakan fungsi atenuasi Donofan (1973), Campbell (1990), Campbell (1993), dan Alfaro (1990). di atas maka diperoleh hasil kurva hazard seperti yang tersaji pada Gambar berikut ini.

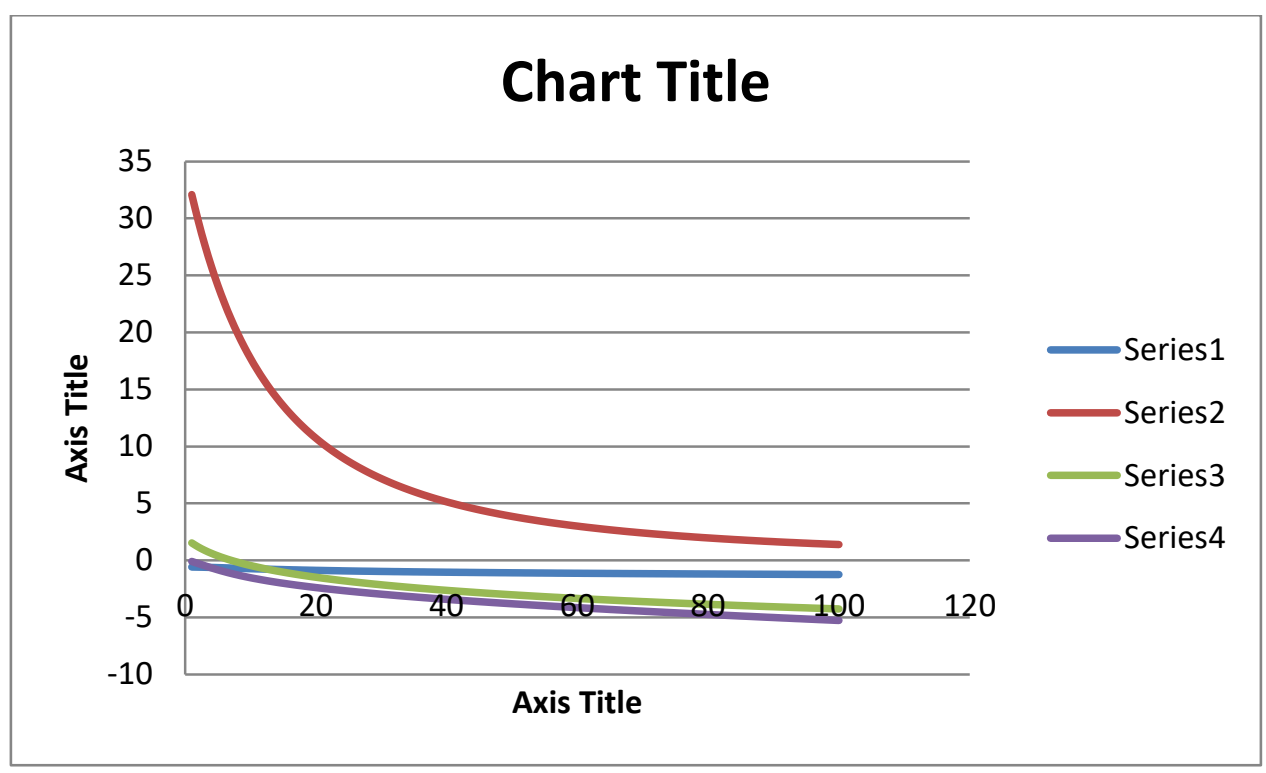


- Series 1 ( Alfaro)

- Series 2 ( donofan)

- Series 3 ( Campbell 1990)

- Series ( Campbell 1993)

Berdasarkan hasil Gambar di atas menunjukkan besarnya nilai percepatan tanah (ground acceleration) akan meningkat seiring dengan besarnya jarak yang diperhitungkan. Hasil penelitian menunjukkan bahwa kurva hazard menunjukkan nilai terbesar pada saat menggunakan fungsi atenuasi donofan., sedangkan nilai terkecil pada kurva hazard terjadi pada saat menggunakan fungsi atenuasi Alfaro (1990) . Kurva hazard ini dapat digunakan dalam menentukan besarnya percepatan tanah di daerah kota Banjarmasin yang disebabkan oleh sumber gempa sesar opak. Hal ini juga dapat dianggap sebagai langkah mitigasi. Upaya mitigasi perlu dilakukan untuk mengidentifikasi bencana yang akan terjadi dikemudian hari dengan mengambil langkah antisipasi. Hal ini dilakukan dalam rangka untuk mengurangi resiko yang ditimbulkan sehingga tingkat kerugian dan korban yang berjatuhan dapat di minimalisir.

\section{Kesimpulan}

Berdasarkan hasil penelitian maka diperoleh beberapa kesimpulan sebagai berikut ini:

1. Besarnya nilai percepatan tanah (ground acceleration) akan meningkat seiring dengan besarnya nilai jarak yang diperhitungkan.

2. Kurva hazard pada daerah kota Banjarmasin akibat sesar akan menunjukkan nilai terbesar pada saat menggunakan fungsi atenuasI donofa.

3. Kurva hazard pada daerah Banjarmasin akibat sesar akan menunjukkan nilai terkecil pada saat menggunakan fungsi atenuasi alfaro 1990.

\section{Daftar pustaka}

1. https://www.scribd.com/doc/30209733/perhitungan-pembebanan-gempa

2. http://www.scribd.com/doc/232424738/PetaSpektra-Hazard-Indonesia-Dengan MenggunakanModel-Gridded-Seismicity-Untuk-Sumber-GempaBackground

3. Irsyam, M., Sengara I.W., Adiamar, F., dan Ridwan,M., 2014. Ringkasan Hasil Studi Tim Revisi PetaGempa Indonesia. http://www.prevention web.net/files/14654_AIFDR. Pdf. 